of land and water; (5) clanges in the position of the earth's axis ; (6) a variation in the amount of heat radiated by the sun; and $(7)$ various temperatures of those regions of space through which the solar system has moved. Discussing each of them, Mr. Wood deals at greater length with the theory advocated by Mr. Croll, arriving at the conclusion that, although the influence of geographical conditions and currents is a powerful agent in modifying climate, nevertheless the cause of the Glacial period must have been a cosmical one; that the cold of this period seems to have fallen upon the earth while its axis was in its present position; and that nothing has yet been found to raise a doubt as to the glaciation of the northern and southern hemispheres having been synchronous. Mr. Wood inclines to admit that it is to the sixth suggested cause, a diminution in the heat emitted by the sun, that the probabilities incline. The discussion of the geological facts connected with the latest changes of climate is the main attraction of the paper of Mr. Wood.

CAYT. Allen Young's Arctic ship Pandora is back again, all well. It will be remembered Capt. Young went out to endeavour to communicate with the Arctic expedition, which he met on its road home.

Two shocks of earthquake were felt at Irkutsk and its neighbourbood, on August 31 at :IO P.M., and on September 4 at I. 30 A.M. Both extended over a large region, and the last was rather strong at Irkutsk.

Two earthquakes are reported as having occurred in Germany on October I4, the one near Kehl at II A.M., and the other at Schopf heim between 8.30 and 9 P.M. The former extended over Strasburg, Kehl, Kork, Auerheim, Zierolshofen, Leutesheim, Linz, Diershein, Rhein-Bischof heim ; the direction was apparently in a south-west-north-east direction. There were three or four shocks lasting about four seconds. The other earthquake was to the north of Schopfheim, at Neuenweg and Gresgen, and was of shorter duration than the former; the direction was apparently north-south.

ThE African explorer, Eduard Mohr, writes to Dr. Nachtigal, under date August 28, of his arrival at St. Paul de Loanda. Within eight days he was to proceed to Malange, on the eastern iimit of Angola, which he was to make his base of operations for an exploring journey to the northern interior.

In the Geological Section of the Helvetic Society of Sciences, besides many interesting smaller communications, the fullowing larger contributions to geological science were made:-The results of a thorough exploration of the earlier geological history of the Black Forest and of the Vosges, by Prof. Sandberger; the results of explorations in the Argovian Jura, by Prof. Muhlberg; the results of explorations by M. Mœsch in the Bernese Alps, accomp nied by a map of the mass of the Faulhorn and of its neighbourhood; a map on the scale of I:250,000 of the glacial deposits of Switzerland, with full particulars as to the former extension of glaciers, their depths, slopes, \&c., made by Prof. Favre; and a very detailed map, on a scale of $x: 5,000$, of the glacier of the Rhone, with all its moraines, moulins, crevices, \&c., constructed by M. Gosse!, at the charge of the Swiss Alpine Club.

At the same meeting Prof. Sandberger presented his work "Land- und Süsswasser-Conchylien der Vorwelt." The terrestrial and fresh-water molluscs are described here in these geological succession, beginning from the oldest formations. Being very abundant in the Tertiary deposits, they have, as is known, much contributed to settle the classification of these deposits.

AT the conversazione of the Chester Society of Natural Science held last month, Mr. Cross exhibited some specimens of Drosera rotundifolia which had been grown in Mr. Siddall's fern case, and which presented characters differing greatly from those of the typical plant. The axis had elongated considerably and bore a number of alternate leaves, quite green, with abortcd tentacles, and several of them showing buds produced on the mid-rib. Some of the old leaves of the original plants placed in the case for preservation also exhibited the phenomenon last named.

WE have received from Dr. C. A. MacMunn an account of the method he proposes for measuring and comparing different spectra with the spectrum microscope. In order to overcome the difficulties due to the difference in the dispersion of different prisms, he proposes to look upon the distance between the Fraunhofer lines $\mathrm{B}$ and $\mathrm{E}$ as equal to $\mathrm{IOO}$, and to express the position of all bands in relation to this scale. We, however, think that it is very desirable not to multiply the already too numerous arbitrary scales of this kind, and would strongly advise him and all others who are studying this subject, to express their results in terms of wave lengths, since, as Mr. Sorby has argued, that system alone has a true physical basis.

The Bethnal Green Museum is becoming just now a great centre of attraction to the multitudes from the numerous interesting collections illustrative of art and science now deposited together. The former speak to the eye for themselves, although the Secretary of the Department has taken care to provide admirable historical and descriptive cheap catalogues. But the scientific and industrial collections require more carefully prepared aids for study, and these are now being furnished by the Department in illustrated manuals, published at a cheap price, written by eminent authors, and on these no expense has been spared to make them thoroughly practical and useful treatises upon the subjects on which they treat. Messrs. Chapmian and Hall, we are informed will publish immediately for the Council of Education and Department of Science, three of these works"Food, its Chemical Constituents and Uses," by Mr. A. W. Chunt, F.C.S., Professor at the Royal Agricultural Colles", Cirencester ; "Economic Entomology," by Mr. Andrew Murray, F.L.S, and "Animal Products, their Preparation, Com. merce, and Uses," by Mr. P. L. Simmonds.

THe additions to the Zoological Society's Gardens during the past week include a Cape Hyrax (Hyrax capentszs) from South Africa, presented by Mr. J. M. Thornton; an Ocelot (Felis par. dalis) from Honduras, presented by Mr. H. Fielding; two Norwegian Lemmings (Lemmus norvegicus) from Norway, presented by Mr. W. Duppa Crotch ; a Common Hangnest (Icteru; zulgaris) from South America, presensed by Mr. J. T. Levett ; an Airican Cobra (Naia haje) from South Alica, presented by the Rev. G. H. R. Fisk; a Vervet Monkey (Corcopithecus lalandh) from South Africa, deposited; two Indian Cobras (Nazia tribitl . aians) from India, received in exchange; a Merlin (Hypotriorchis cesalon), European, purchased.

\section{SEXUAL SELECTION IN RELATION TO MONKEYS}

IN the discussion on Sexual Selection in my "Descent of 1 Man," no case interested and perplexed me so much as the brightly-coloured hinder ends and adjoining parts of certain moxkeys. As these parts are more brightly coloured in one sex than the other, and as they become more brilliant during the season of love, I concluded that the colours had been gained as a sexuaI attraction. I was well aware that I thus laid myself open to ridicule; though in fact it is not more surprising that a monkey should display his bright-red hinder end than that a peacoek should display his magnificent tail. I had, however, at that time no evidence of monkeys exhibiting this part of their bodies during their courtship; and such display in the case of birds affords the best evidence that the ornaments of the males are of service to them by attracting or exciting the females. I have lately 
read an article by Joh. von Fischer, of Gotha, published in Der Zoologische Gartin, April, 1876 , on the expression of monkeys under various emotions, which is well worthy of study by any one interested in the subject, and which shows that the author is a careful and acute observer. In this article there is an account of the behaviour of a young male mandrill when he first beheld himself in a looking-glass, and it is added, that after a time he turned round and presented his red hinder end to the glass. Accordingly I wrote to Herr J. von Fischer to ask what he supposed was the meaning of this strange action, and he has sent me two long letters full of new and curious details, which will, I hope, be hereafter putlished. He says that he was himself at first perplexed by the above action, and was thus led carefully to observe several individuals of various other species of monlkeys, which he has long kept in his house. He finds !hat not only the mandrill (Cy'nocephalus mormon) but the drill (C. Ieucopha:us) ard three other kinds of baboons $(C$. hamadryas, sthinx, and baboun), also Cynofithecus niger, and Macacus whesus and nemestrinus, turn this part of their bodies, which in all these species is more or less brightly coloured, to him when they are pleased, and to other persons as a sort of greeting. He took pains to cure a Macacus rhesus, which he had kept for five years, of this indecorous babit, and at last succeeded. These monkeys are particularly apt to act in this manner, grinning at the same time, when first introduced to a new monkey, but often also to their o'd monkey friends; and after this mutual display they begin to play together. The young mandrill ceased spontareously after a time to act in this manner towards his master, von Fischer, but continued to do so towards persons who were strangers and to new monkeys. A young Cynopithecus niger never acted, excepting on one occasion, in this way towards his master, but frequently towards strangers, and continues to do so up to the present time. From these facts von Fischer concludes that the monkeys which behaved in this manner before a looking-glass (viz., the mandrill, drill, Cynopithecus niger, Macacus rhesu, and nemustrinus) acted as if their reflection were a new acquaintance. The mandrill and drill, which have their hinder ends especially ornamented, display it even whilst quite young, more frequently and more ostentatiously than do the other kinds. Next in order comes Cynocephalus hamadryas, whilst the other species act in this manner seldomer. The individuals, however, of the same species, vary in this respect, and some which were very shy never displayed their hinder ends. It deserves especial attention that von $F$ ischer has never seen any species purposely exhibit the hinder part of its body, if not at all coloured. This remark applies to many individuals of Macacus cynomolgus and Cercocebus radiatus (which is closely allied to $M$. rhesus), to three snecies of Cercopithecus and several American monkeys. The habit of turning the hinder ends as a greeting to an old friend or new acquaintance, which seems to us so odd, is not really more so than the habits of many savages, for instance that of rubbing their bellies with their hands, or rubbing noses togetler. The habit with the mandrill and drill seems to be instinctive or inherited, as it was followed by very young auinals; but it is modified or guided, like so many other instincts, by observation, for von Fischer says that they take pains to make their display fully, and if made before iwo observers, they turn to him who seems to pay the most attention.

With respect to the origin of the babit, von Fischer remarks that his monkeys like to have their naked hinder ends patted or stroked, and that they then grunt with pleasure. They often also turn this part of their bodies to other monkeys to have bits of dirt picked off, and so no doubt it would be with respect to thorns. But the habit with adult animals is connected to a zertain extent with sexual feelings, for von Fischer watched through a glass door a female Cynopithocus niger, and she during several days, " umdrehte und dem Männchen mit gurgelnden Tönen die stark geröthete Sitzfiäche zeigte, was ich fruber nie an diesem Thier bemerkt hatte. Beim Anblick dieses Gegenstandes erregte sich das Männchen sichtlich, denn es polterte heftig an den Stäben, ebenfalls gurgelnde Laute ausstossend." As all the monkeys which have the hinder parts of their bodies more or less bright coloured live, according to von Fischer, in open rocky places, he thinks that these colours serve to render one sex conspicuous at a distance to the other; but as monkeys are such gregarious animals, I should have thought that there was no need for the sexes to recognise each other at a distance. It seems to me more probable that the bright colours, whether on the face or hinder end, or, as in the mandrill, on botb, serve as a sexual ornament and attraction. Anyhow, as we now know that monkeys have the habit of turning their hinder ends towards other monkeys, it ceases to be at all surprising that it should have been this part of their bodies which has been more or less decorated. The fact that it is only the monkeys thus characterised which, as far a at present known, act in this manner as a greeting towards other monkeys, renders it doubtul whether the habit was first acquired from some independerit cause, and that afterwards the parts in question were coloured as a sexual ornament; or whether the colouring and the habit of turning round were first acquired through variation and sexual selection, and that afterwards the habit was retained as a sign of pleasure or as a greeting, through the principle of inherited association. This principle apparentiy comes into play on many occasions: thus it is generally admitted that the songs of birds serve mainly as an attraction during the season of love, and that the leks, or great congregations of the black grouse, are connected with their courtship; but the habit of singing has been reiained by some birds when they feel happy, for instance by the common robin, and the habit of congregating has been retained by the black grouse, during other seasons of the year.

$x$ beg leave to refer to one other point in relation to sexual selection. It has been objected that this form of selection, as far as the ornaments of the males are concerned, implies that all the females within the same district must possess and exercise exactly the same taste. It should, however, be observed in the first place, that although the range of variation of a species may be very large, it is by no means indefinite. I have elsewhere given a good instance of this fact in the pigeon, of which there are at least a hundred varieties differing widely in their colours, and at least a score of varieties of the fowl differing in the same manner; but the range of colour in these two species is extremely distinct. Therefore the females of natural species cannot have an unlimited scope for their taste. In the second place, I presume that no supporter of the principle of sexual selection believes that the females select particular points of beauty in the males; they are merely excited or attracted in a greater degree by one male than by another, and this seems often to depend, especially with birds, on brilliant colouring. Even man, excepting perhaps an artist, does not analyse the slight differences in the features of the woman whom he may admire, on which her beauty depends. The male mandrill has not only the hinder end of his body, but his face gorgeously coloured and marked with oblique ridges, a yellow beard, and other orna. ments. We may infer from what we see of the variation of animals under domestication, that the above several ornaments of the mandrill were gradually acquired by one individual varying a little in one way, and another individual in another way. The males which were the handsomest or the most attractive in any manner to the females would pair oftenest, and would leave rather more offspring than other males. The offspring of the former, although variously intercrossed, would either inberit, the peculiarities of their fathers, or transmit an increased tendency to vary in the same manner. Consequently the whole body of males inhabiting the same country, would tend from the effects of constant intercrossing to become modified almost uniformly, but sometimes a little more in one character and sometimes in another, though at an extremely slow rate; all ulimately being thus rendered more attractive to the females: The process is like that which I have called unconscious selection by man, and of which I have given several instances. In one country the inhabitants value a fleet or light $d o g$ or horse, and in another country a heavier and more powerful one ; neither country is there any selection of the individual animals with lighter or stronger bodies and limbs ; nevertheless after a considerable lapse of time the individuals are found to have been modified in the desired manner almost uniformly, though differently in each country. In two absolutely distinct countries inhabited by the same species, the individuals of which can never during long ages have intermigrated and intercrossed, and where, moreover, the variations will probably not have been identically the same, sexual selection might cause the males to differ. Nor does the belief appear to me altogether fanciful that two sets of females, surrounded by a very different environment, would be apt to acquire somewhat different tastes with respect to form, sound, or colour. However this may be, I have given in my "Descent of Man" instances of closely-allied birds inhabiting distinct countries, of which the young and the females cannot be distinguished, whilst the adult males differ considerably, and this may be attributed with much probability to the action of sexual selection.
CHARLES DARWIN 